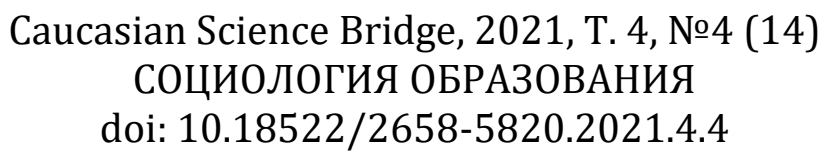

Научная статья

УДК 316.334:37

https://doi.org/10.18522/2658-5820.2021.4.4

\title{
Could Online Learning Substitute the Traditional one in Bulgarian Universities: Lecturers' Point of View
}

\author{
Antoaneta G. Getova ${ }^{1}$ \\ 1Sofia University “St. Kliment Ohridski”, Sofia, Bulgaria \\ e-mail: tony22a@gbg.bg
}

\begin{abstract}
The COVID-19 pandemic affected many spheres of the social life, including the higher education. Since March 2020 , university education in Bulgaria is held almost online, with the perspective the online learning to continue even during the second semester of the academic 2021-2022. The article is dedicated to lecturers' point of view about the first three semesters of online leaning in Bulgarian universities: what are the advantages and disadvantages of online learning and, according to them, if it could eventually substitute the traditional one. The perceptions and attitudes of lecturers are crucial for potential introduction of the online learning after the end of the pandemic as lecturers are the main actors in such process. The article analyses results of empirical online research made in the summer of 2021.77 lecturers and 253 students of different Bulgarian universities and programs took part in the research. This article focuses on lecturers' opinions only that is researched less often, than students' one.

Keywords
\end{abstract}

COVID-19; online learning; digitalization; higher education; online research.

For citation

Getova A. (2021). Could Online Learning Substitute the Traditional one in Bulgarian Universities: Lecturers'

Point of View. Caucasian Science Bridge, 4 (4), P. 34-44. https://doi.org/10.18522/2658-5820.2021.4.4

\section{Сможет ли онлайн-обучение заменить традиционное в болгарских университетах: точка зрения преподавателей}

\author{
Антоанета Г. Гетова ${ }^{1}$ \\ ${ }^{1}$ Софийский университет Св. Климента, г. София, Болгария \\ e-mail: tony22a@gbg.bg
}

\begin{abstract}
Аннотация
Пандемия COVID-19 затронула многие сферы общественной жизни, в том числе высшее образование. C марта 2020 года университетское образование в Болгарии проводится практически онлайн, с перспективой продолжения онлайн-обучения даже во втором семестре академического 2021-2022 . Статья посвящена точке зрения преподавателей на первые три семестра онлайн-обучения в болгарских университетах, его преимущества и недостатки, и может ли оно заменить традиционное. Восприятие и отношение лекторов имеют решающее значение для потенциального внедрения онлайн-обучения после окончания пандемии, поскольку лекторы являются основными действующими лицами в этом процессе. В статье анализируются результаты эмпирического онлайн-исследования, проведенного летом 2021 года. В исследовании приняли участие 77 преподавателей и 253 студента различных болгарских университетов и программ. В данной статье основное внимание уделяется мнениям преподавателей, которые редко исследуются, в отличие от мнения студентов.
\end{abstract}

Ключевые слова

COVID-19; онлайн-обучение; цифровизация; высшее образование; онлайн-исследования.

Для цитирования

Гетова А. Г. (2021). Сможет ли онлайн-обучение заменить традиционное в болгарских университетах: точка зрения преподавателей. Caucasian Science Bridge, 4 (4), C. 34-44. https://doi.org/10.18522/26585820.2021.4.4 


\section{Introduction}

The pandemic of COVID-19 led to unprecedented changes in many countries all over the world. During the spring of 2020 some experienced the first total lockdown in their history that affected many spheres of the social life, including the university education that had to be transferred online.

Bulgaria was no exception to this tendency: since March 2020 practically all the universities held online all the classes of the second semester of the academic year 2020 2021. The concept of online learning is not a brand new approach in the higher education: including in Bulgaria there were already several programs in different universities that relied only on online or/and distance learning, the approach is also object of academic interest from a very long time (Halachev, 2009). However, the lockdown put the universities in totally different situation. First, the programs and courses that were meant to be held in campus should be transferred online and second, that should be made in a very stretched time period. The abrupt and sudden changes brought many problems and challenges during the transition (and after it) so in the country and all over the world it attracted a very high academic interest: many surveys that were dedicated of the effects of the online learning on the participants in the educational process were made in $2020 \mathrm{such}$ as these by Mulroney and Kelly (UK, 2020), Firang (Canada, 2020), Tokmakova, Bondarenko and Lunitsina (Russia, 2020). As Bulgarian example of the latter could be cited the survey about the students' attitudes to the online university course of management in the University of National and World Economy (Angelova, 2020) and the pilot survey of students and lecturers of two Bulgarian universities about the problems and perspectives of distance learning during the first lockdown (Getova, 2020). A search in the biggest academic platforms Web of science and Scopus shows that in 2020 more than 1000 articles (in English) were published in journals available in Scopus or Web of Science; respectively in Google Scholar there are even more than 29000 results of articles, conference papers or preprints dedicated to the topic of the higher education and the online learning. In 2021, however, this tendency changes: in Scopus/Web of science the number of published article is already around 700 and in Google Scholar is less than 10000 (till the end of October 2021). A more sophisticated analysis of these results shows that not all of the articles contain results of real research made on the topic; some even contain only observations and impressions of the courses held by lecturers during the periods of the university lockdown. As is shown in content analysis presented during the 15 ESA Conference in 2021, less than 400 of the 1000 mentioned articles of Scopus/Web Sciences journals contain any kind of empirical data (Stoykova and Getova, 2021). However, the search results for both years (2020 and 2021) undoubtedly show that the academic interest towards the problem is higher during the first year of online learning).

This drop of academic interest during the second year of the pandemic can be explained by various reasons. One of them is that during the next academic year (2020-2021) some universities made attempts for introducing hybrid or partially in person learning, so respectively the online learning began to "step back" to other approaches. The situation in Bulgaria was all the opposite.

During the academic year 2020-2021 most programs in the Bulgarian universities were held primarily online with the tendency to continue even during the next year: even during the first semester of the academic year 2021-2022 in most university programs in Bulgaria the classes are held online. The situation, considered in March 2020 as something temporary, endured 3 semesters with the possibility to continue even more. This raises important questions as could the "temporary" situation of online learning cause more permanent changes in the university education and how the main participants in the process, i.e. students and lecturers react to it, what are their opinions about the biggest problems and challenges of the online education. While the online learning in the second year of the 
pandemic attracted less academic interest for similar surveys in the country (as the survey of Georgieva-Tsaneva and Serbezova of students of nursing), the almost permanent presence of the online learning since March 2021 in the Bulgarian university is a proof that the topic is important enough to be researched.

Most of the articles cited above have their main focus on the students as the learners are naturally the main subject in the educational process. The mentioned analysis by Stoykova and Getova about the publications of 2020, also shows that the majority of them are focused indeed on the students. Few reports and articles (Dooolan et al., 2020, Kuleva 2020 ) also include or focus on the other side of the process, i.e. the lecturers. The opinion of the lecturers is crucial as they are those who practically introduced and adapted the new approach in the Bulgarian universities: even without previous experience, previous training or instructions: the first institutional document published by the Ministry of Education of Bulgaria on this matter came out in 2021. (Strategy for development of higher education in Republic of Bulgaria 2021-2030, 2021).

One of the surveys that focuses also on lecturers and not only on the students was made by members of the same team that made the pilot survey mentioned above. The purpose of the present paper is to analyze the opinions of the lecturers in Bulgarian universities regarding to the main problems and opportunities the lecturers had during the three semesters online and also their general attitude towards the online learning.

\section{Main hypotheses}

The first main hypothesis is that while the lecturers succeeded to adapt to the educational process online and appreciate its advantages, they still consider this approach as less effective than the traditional one.

The second hypothesis is that the lecturers consider the limited possibilities for real time interaction with the students as the main flaw of the online learning. These limited possibilities cause the feeling of disrupted or even non-existing educational process.

Respectively, most of the lecturers do not prefer the online approach except in emergency situations as is the pandemic.

\section{Methodological limitations of the research}

The research was made online in the end of the academic year 2020-2021 (in the summer of 2021). The research is a continuation of a pilot survey made by members of the same teams during the first lockdown in Bulgaria. The indicators in the new survey are based on those used in the pilot; however some of them were modified after the results received in the pilot survey, also new one were added to follow the changes during the next semesters held online The full report in Bulgarian is published on: https://phls.uni-sofia.bg/article/3052. (Getova, 2021)

77 lecturers and 253 students of different Bulgarian universities and programs took part in new survey. The questionnaire for students and lecturers were separate, although some indicators were included in both questionnaires with the purpose of comparison.

This analysis focuses on the lecturers' opinion only.

The demographic profile of the sample of lecturers can be seen in Table 1 . All the respondents had online classes during the mentioned period.

A sample of snowball type was used (Biernacki and Waldorf, 1981).

While it is a non-representative type of sample, it gives the opportunity to collect opinions from different subgroups as is presented in Table 1 and in this way it is possible to register the main tendencies within the target group of the research and respectively to fulfill its purposes. 
Demographic profile of the sample

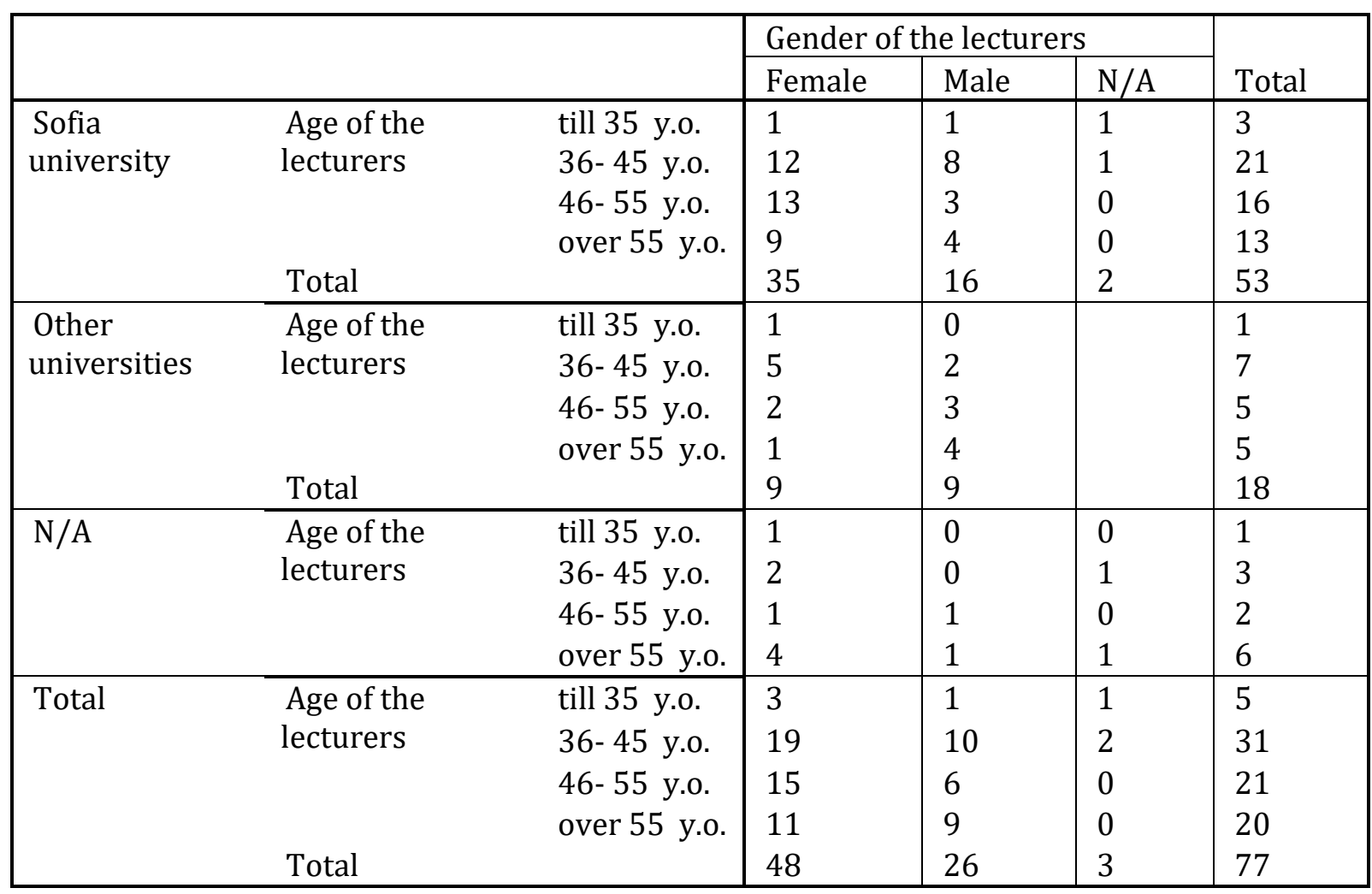

\section{Analysis of the results}

While the survey mentioned above has wider scope, in this part of the paper are commented results related to the main hypotheses.

The question if the lecturers had really adapted to the online learning during the three semesters since the beginning of the pandemic was never asked directly in the survey. Instead of these was included series of indicators that follow the main aspects of the process of teaching online and how it changed compared to the beginning of the online learning (in March 2020).

As was mentioned above, the fast and unexpected introduction of the online learning didn't give to the lecturers enough time to adapt the process of teaching to online environment that caused series of problems in the process. After the first semester online however, the lecturers already had enough experience with the teaching online and could overcome at least part of the problems in the beginning, to adapt better the educational process to the new environment. In fact, most of them consider that the teaching online during the next year grew better compared with the beginning of the pandemic. This is shown in detail in Figure 1.

As it can be seen in the figure, the biggest improvement in comparison with the previous year is the technological preparation to teach online. It is not surprising, as the experience with the online learning before the pandemic for most of the lecturers was small or even non-existent.

During the first semester online they had the opportunity to acquire enough practical experience with teaching in virtual environment.

Most of the lecturers consider the time for preparation for the classes and their possibilities to provide learning resources good as it was or even better than the previous year.

The organization of the exams is also considered as successful as /more successful than the previous year. It can be concluded that the main aspects of the online teaching, according to the lecturers are improved in the course of the three semesters online. However, the more "personal" aspects of the teaching as is the motivation to teach online didn't improve at all: the 
share of those who think that the things are worse in this aspect $(21 \%)$ is similar to the share of those who think that it is better than the previous year $(23 \%)$.

\section{Comparison between the online teaching during the first and the second year of the pandemic}

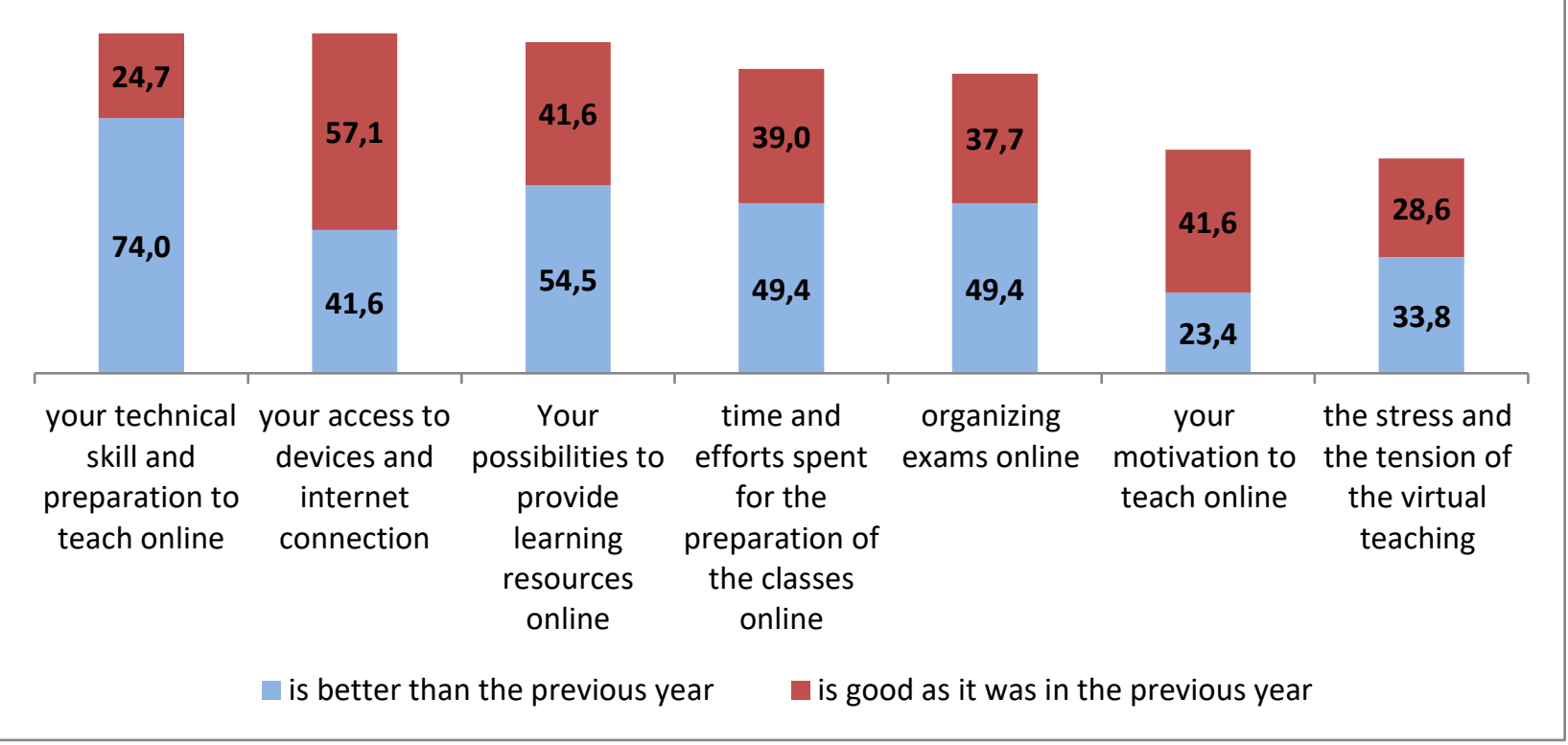

Figure 1. Comparison between the online teaching during the first and the second year of the pandemic. Source: Getova, 2021.

While $42 \%$ think that their motivation is as good as it was the previous year, the share of those who think that is bad as or even worse, is significant (34\% in total). Similar tendency can be seen about the stress and the tension of teaching in virtual environment: while the majority still thinks that in this aspect is good as or better in comparison to the previous year, almost $29 \%$ think that the situation is bad as or even worse. It is in a way paradoxical that the technical "adjustment" and the improvement of the organization of the learning process online during the time is accompanied with decreasing motivation and increasing stress for the lecturers. It can be concluded that no matter that they obviously adapted to the teaching online, they don't feel comfortable about it; on the contrary, in time it is highly probable that their motivation to teach online would ever decrease more.

The explanation of this can be found in the way the lecturers perceive the online learning as whole and what they consider as its major flaws and problems and respectively, its advantages.

In the next figure, it can be seen what the lecturers consider as major disadvantages of the online learning.

First, it should be clarified that this indicator is based on open-ended question asked during the pilot survey in 2020. In the next survey, the questions about the advantages and the disadvantages of the online learning were closed with statements based on the most popular spontaneous answers for both students and lecturers with additional open-ended option for 'other'. As the answers for 'other' in both questions (about advantages and disadvantages) are marked by less than 5 lecturers, it can be concluded that these indicators were successfully operationalized in the survey and the scale used is adequate enough to show the main strengths and flaws of the online learning according to lecturers. 
Three of the most frequently chosen options about the disadvantages of the online learning are related to different aspects of the communication with the students, including during the classes and the informal communication out of the classes. While the latter is not an essential part of the educational process itself, for the lecturers it is obviously important to have it with the purpose to maintain more constant contact with the learners.

During the process of online learning, however, is much more difficult to maintain such contact: for example, there are no real breaks between the classes, or at least no breaks in which the lecturers and students could stay together and communicate to each other. The lecturers do use different channel of communications to contact with the students, i.e. they don't count only on the platform of online learning, but the most used additional channel is the email (mentioned by $93 \%$ of the respondents) that offers only possibilities for indirect communication.

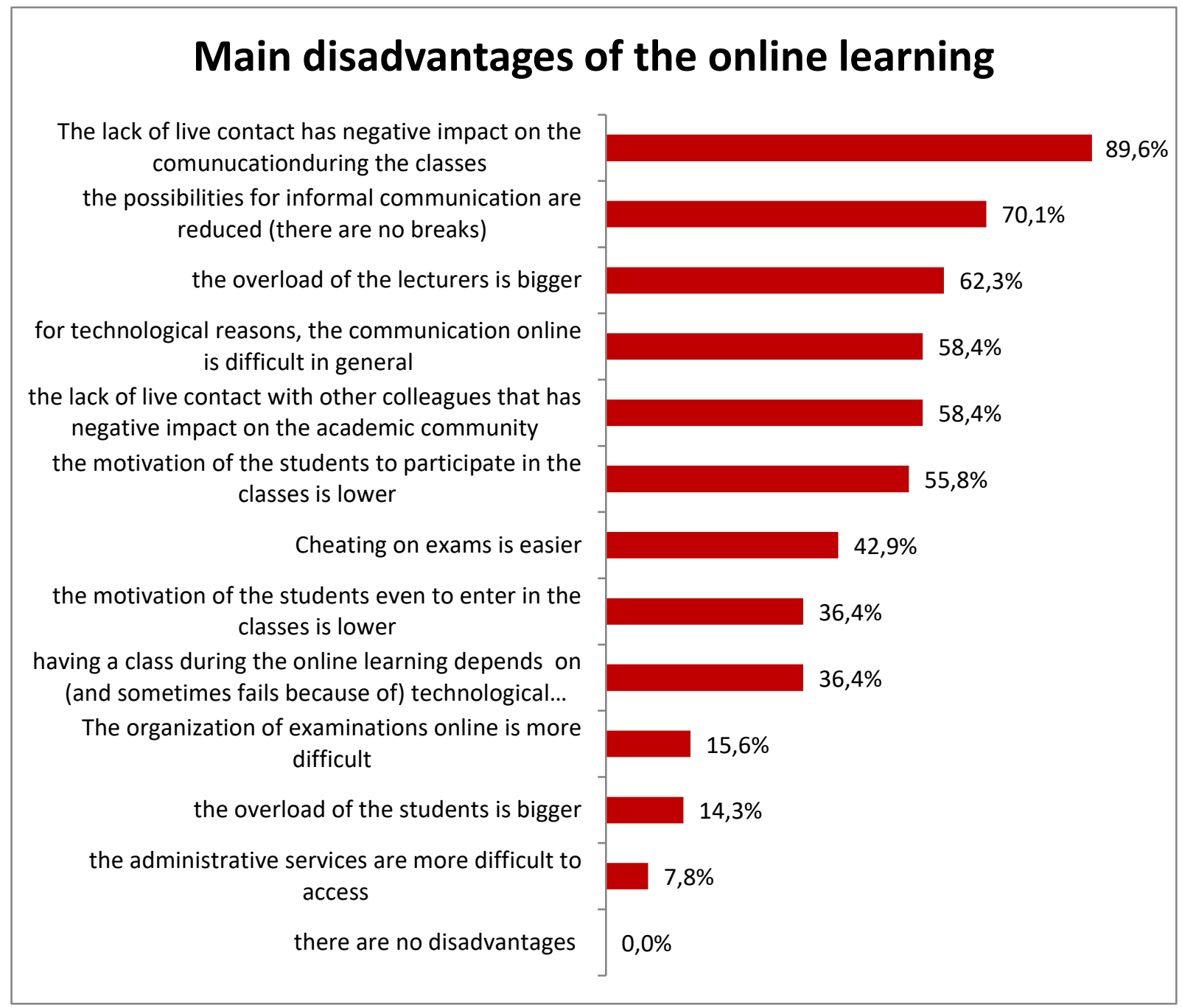

Figure 2. Main disadvantages of the online learning. Source: Getova, 2021.

Is not less difficult to maintain such contact during the classes as for technological reasons the communication is not direct but mediated by the technology. It is important to mention also that more than $80 \%$ of the lecturers answer that the students generally enter without cameras during the classes (only with audio connection or even like listeners) so the communication during the classes is partial and even cannot be considered as virtual equivalency of the real time communication for the lack of visual contact.

This lack of visual contact is not a characteristic by default for the online learning, however, for practical reasons described also in the open-ended questions (technical problems, crash of the platforms for online learning, poor Internet connection) the most frequent contact between students and lecturers during the last three semesters is only by audio connection or 
even chat. This circumstance has negative impact especially on the feedback, as the lecturers can barely receive such.

Is not surprising then that almost $90 \%$ of them mention the lack of live contact with the students as the biggest disadvantage of the online learning as this circumstance affects in a very negative way the process of communication during the classes (and out of them). Also, the lecturers consider as major flaw of the online learning process the lack of live contact with other colleagues in the academic community. While the communication with the other lecturers is not essential part of the educational process itself, for the lecturers this situation of alienation (for the lack of live contacts) affects very negatively the academic community.

Apart from the different problems related to the communication online, another very frequently mentioned disadvantage of the online learning according to lecturers is their overload. More than $60 \%$ of them think that the amount of work and efforts during the online teaching is bigger. Most of them do not think that the overload of students is bigger so it can be concluded that they consider the online learning as harder and more exhausting not in general for all participants but especially for the teachers in the process. It is not surprising that they are critical towards this approach and that few of them prefer it instead of the traditional one (see below).

The lecturers also mentioned as big disadvantage the lower motivation of the students to participate in the classes (compared with the situation in person). This can be related to the problems of the communication: as for technical reasons the students have more passive role during the classes, they inevitable would lose the enthusiasm to participate in them, or at least this is the lecturers' impression. Of course, it could be speculated that there is no real lack of motivation by the students but this impression comes from the limited feedback the lecturers receive, but even in this case, this is obviously seen as problem in educational process online. It is important to mention also that almost 39\% of the lecturers also think that the students' motivation to participate in the classes was bad as or even worse than the previous year.

The Cramer's V coefficient between the two indicators shows moderate correlation (the value of Cramer's $\mathrm{V}$ is 0.50 ): the majority of lecturers who think that the motivation of students is generally lower during the online learning also think that this motivation decreased over time: i.e. the problem of students' motivation according to them would become even bigger if the online learning continues.

This coefficient is used in the analysis as the most appropriated for the type of the sample and indicators included (Kraska-Miller 2013, 70-71).

$42 \%$ of the lecturers are also worried by the possibility of easier cheating during the online exams. While the technology implemented in the online platforms also gives some level of protection against cheating, especially if the exam is in the form of test with close-ended questions, the worry of more cheating could be also a result of the lack of feedback or "control" (if the lecturer practically cannot see what exactly the students are doing during the exams, it is probable to think that the students will use this opportunity to search information in Internet resources, for example).

While the lecturers are generally critical towards the online approach, they also recognize its advantages. The distribution of answers to this question is shown in Figure 3.

As it can be seen on the figure, the aspects most frequently recognized as advantages by the lecturers are mostly technological and organizational: flexibility, easier organization of resources, time effectiveness. More than $80 \%$ think that saving time is the biggest advantage of the online learning. This is a direct result of the fact that the online learning is virtual: it doesn't require a physical location to be organized and so it saves time from traveling to this particular location and also, of the organization of the working day. It is not necessary for the agenda of the classes to be organized in different way than the agenda of the in person learning, but as the necessity to go to the location of the classes doesn't exist, the tasks for the day could be organized more effectively than with the same program of classes but in person learning, 


\section{Main advantages of the online learning}

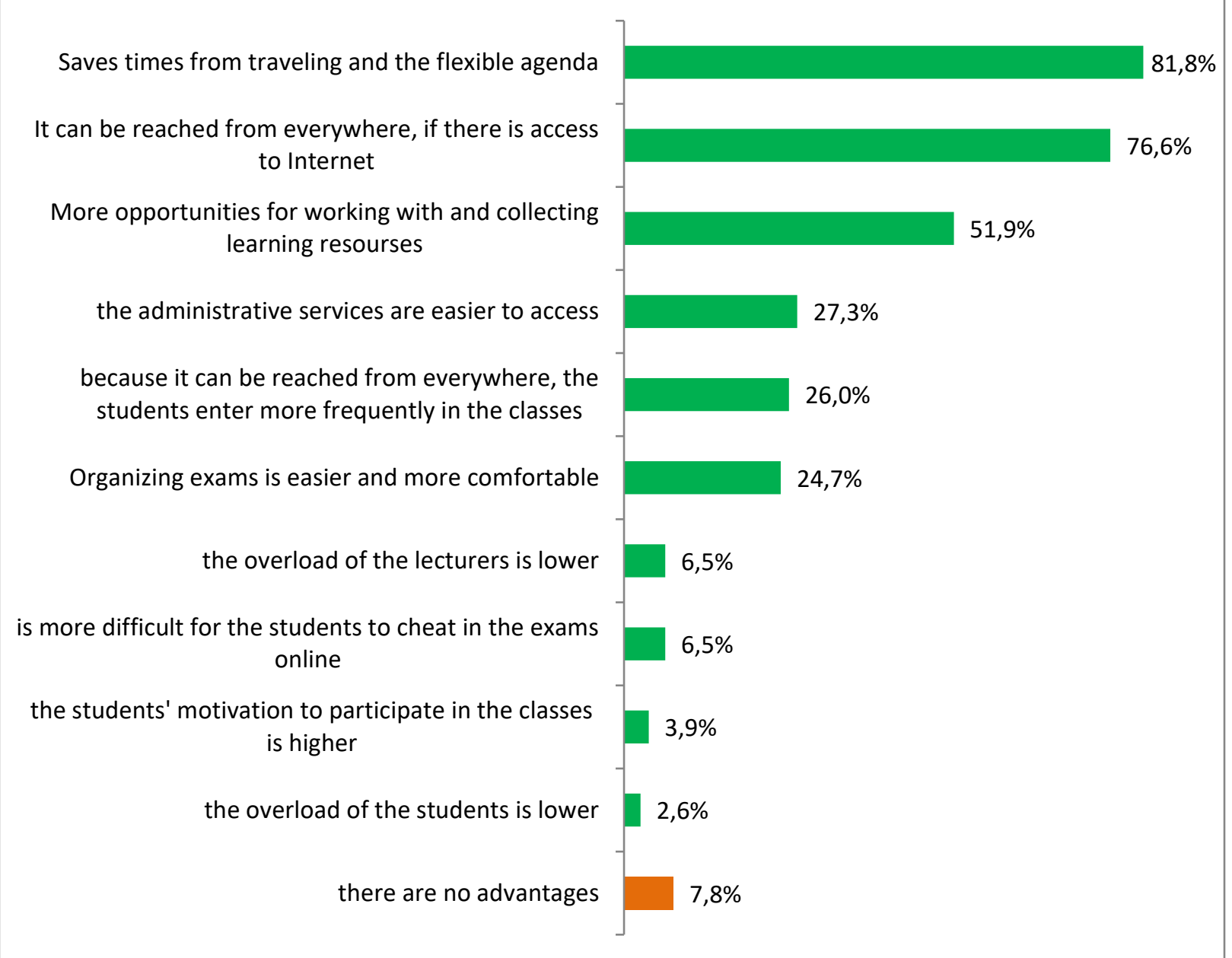

Figure 3. Main advantages of the online learning. Source: Getova, 2021.

This flexibility of the online learning comes by the fact that the platforms for teaching can be accessed practically form everywhere and give enough technological facilitations as sharing screen, using virtual whiteboard and so on, the lecturer needs only internet connection and access to a device that could be used during the teaching. It gives the opportunity to the lecturers (and the students) to reach the virtual classroom from practically everywhere, especially in the case if they use a mobile device or laptop.

This flexibility doesn't automatically lead to increased number of students during the online classes: only $26 \%$ of the lecturers agree with this statement. The technological easiness of the process doesn't lead to increased motivation for the students to participate in the classes either: only 3 of all 77 lecturers had chosen this option. Most of the lecturers actually think that the motivation of students is lower during the online learning (see above).

Working with learning resources is another advantage of the online learning, according to $52 \%$ of the lecturers. Most platforms used for online learning as MS Teams, Moodle and others mentioned by the lecturers, offer opportunities for online storage of files and also records of the classes that facilitates not only the students but the lecturers as they invest less efforts to acquire and give access to such resources.

Another advantage according to lectures is the development of the academic activities in virtual environment as: organizing and participating in scientific conferences, working on academic projects and so on. While these options were not part of the question of the advantages of the online learning, they were included in separate indicator about the assessment of the academic life itself. The results are shown in the next figure. 
It can be concluded that the possibilities to participate in academic events and activities were mostly unaffected or even increased online. While these activities are not direct part of the educational process itself, they are essential part of the work of the lecturers and it is important to see what the lecturers think about this matter.

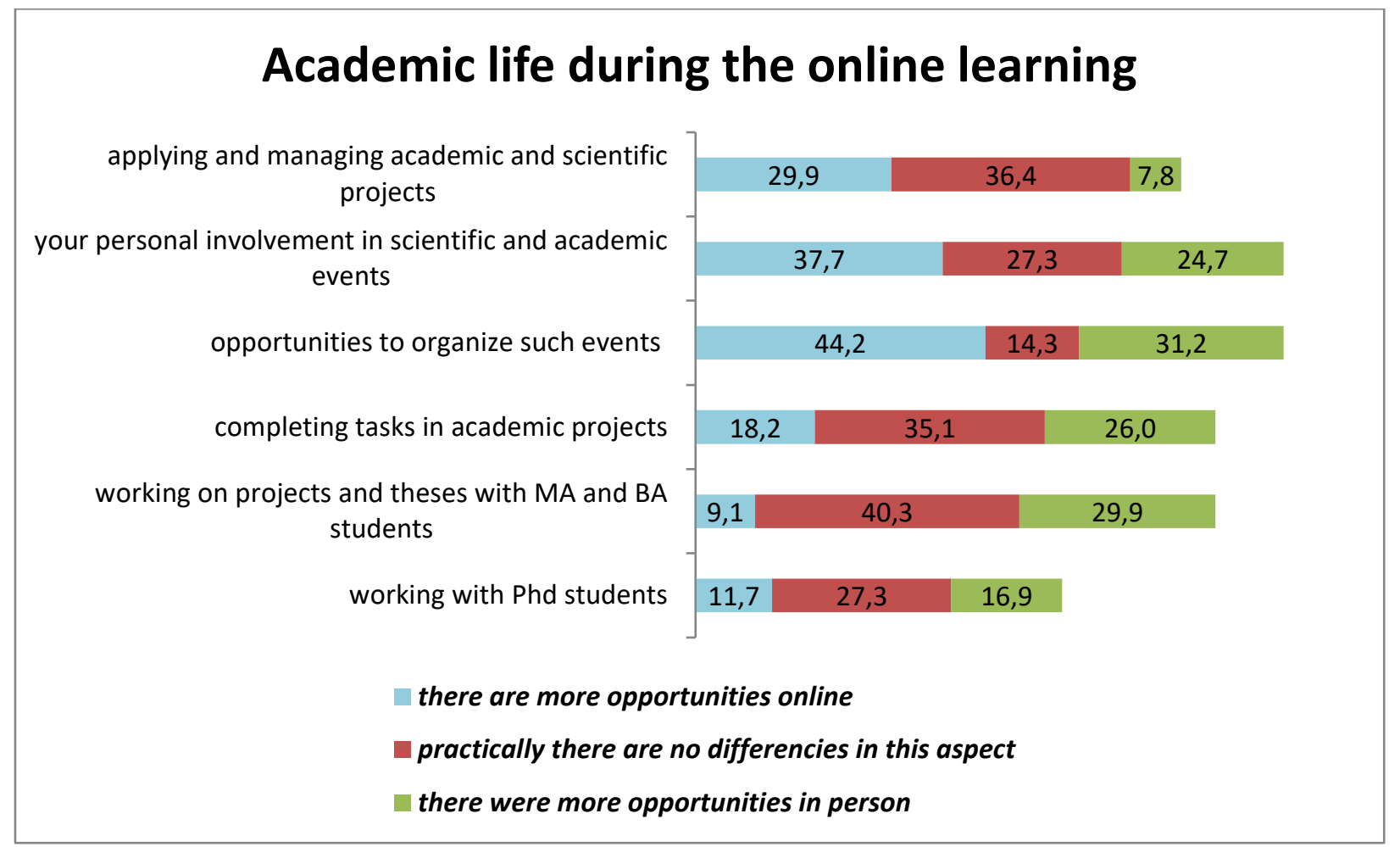

Figure 4. Academic life during the online learning. Source: Getova, 2021.

As can be seen in the figure, most of the lecturers think that online they have even more opportunities to participate in conferences (congresses and similar), to organize such events and to participate in academic projects. About the working tasks in such projects, most of them consider that the opportunities online and in person are the same; the situation is similar regarding the individual work with students on BA, MA or PHD theses. Obviously, according to lecturers this part of their work is unaffected or even amplified in virtual environment.

While all these advantages are appreciated by the majority of lecturers, in general they are more critical towards the online learning. For example, only 5 of all 77 lecturers prefer this approach of teaching instead of the traditional one. The explanation of this can be found in the problems and the disadvantages it demonstrates in comparison to the traditional in person approach. Moreover, $68 \%$ of them agree with the statement that the online learning would never fully substitute the in person approach, and $77 \%$ think that, apart from the emergency situation nowadays, the online learning is appropriate as supplementary form of education. This skepticism about the online learning in general is based on the experience they have in the past three semesters: no matter that the online learning gives enough technical and organizational advantages and also stimulates the development of academic events and projects, it also limits the communication between students and lecturers which leads to difficulties in the educational process itself.

\section{Conclusion}

According to the analysis above, during the past three semesters in pandemic in Bulgaria, the lecturers succeeded to adapt the teaching process to the new virtual environment, although not without problems. That confirms the first hypothesis of the research. 
The main problems are not related to technical or organizational aspects of the online learning but to more personal factors as the motivation to teach online and the decreasing motivation of the students to participate in the classes online. The latter is considered as one of the flaws of the online learning in general. The biggest disadvantages of the online learning, according to the lecturers, are the limitations in the communication between them and the students, including the informal communication that in virtual environment is very reduced or even nonexistent that confirms the second hypothesis. The alienation in the educational process online: both between students and lecturers and even within the academic community itself, is considered as one of the biggest flaws of the online learning. Another big disadvantage, according to lecturers is their work overload online.

The online approach has also its advantages. Such according to the lecturers in the survey are the technological and organizational aspects of the online learning: flexible agenda, saving time, working with resources. However, these facilitations hardly overcome the disadvantages of the online learning for the lecturers: they consider it appropriate only as supplementary form of education (apart from the pandemic time) and also the majority of them do not prefer this approach instead of the traditional one.

The last statistics of the pandemic show that it will endure at least in the next year which would continue to affect the higher education in Bulgaria. The attitudes and perceptions of the lecturers about the online learning are crucial for the successful (or unsuccessful) introduction and continuation of the approach as the lecturers are those who have to handle the main part of the process. While the research described above is not based on representative sample, it succeeds to register the main tendencies in the attitude of the lectors that is very skeptical towards the opportunities and results of the online learning as basic approach in the higher education.

\section{References}

Angelova, M. , (2020). Students' Attitudes to the Online University Course of Management in the Context of COVID-19, International Journal of Technology in Education and Science (IJTES), 4(4), 283-292.

Biernacki, P, and D Waldorf. (1981). Snowball Sampling: Problems and Techniques of Chain Referral Sampling. Sociological Methods and Research, 10, 2, Sage Publications, 141-163

Doolan, Karin et al. (2020). Student Life during the COVID-19 Pandemic Lockdown: Europe Wide Insights, Draft Report. Available at: http://www.ehea.info/Upload/BFUG_DE_UK_73_11_6_students_Covid_19_survey_results.pdf

Firang, David. (2020). COVID-19 pandemic on international students in Canada. International Social Work, Sage Publications, 63(6), 820-824

Georgieva-Tsaneva, G., and Serbezova, I., (2021) Online Training and Serious Games in Clinical Training in Nursing and Midwife Education. International Journal of Advanced Computer Science and Applications(IJACSA),12, $5,317-322$

Getova, A. (2020). Problems and challenges to the distance learning during the emergency situation. (Research Report). Available at: https://phls.uni-sofia.bg/article/3052.

Getova, A. (2021). Attitudes and expectations towards the online learning during the second year of the pandemic (Research Report). Available at: https://phls.uni-sofia.bg/article/3052

Halachev, P. (2009). Educational Challenges for e-Learning in Higher Education in Bulgaria. International Journal of Learning, 16, 6, 737-745.

Mulrooney, Hilda Mary, Helly Alison Faith (2020). COVID-19 and the move to online teaching: impact on perceptions of belonging in staff and students in a UK widening participation university. Journal of Applied Learning \& Teaching, 3, 2, 1-14.

Kraska-Miller, M. (2014). Nonparametric Statistics for Social and Behavioral Sciences. Boca Raton, CRC Press.

Kuleva, M. (2020). The impact of COVID-19 Pandemic on the evaluation of the effectiveness of online distance learning, Pedagogy, 92, 7S, 74-83

Stoykova, E. and Getova, A. (2021).The "Fast And Dubious" Research On Higher Education During Covid19 Pandemic: Where Did Sociology Go?, Oral presentation at the 15th ESA Conference, Barcelona. Available at: https://www.europeansociology.org/esa-conference-2021-in-barcelona

Tockmakova, S.I., Bondarenko O.V., Lunitsina, YU. V. (2020). The experience on the distance learning of the students of the stomatology faculty in the situation of the pandemic of COVID-19, Contemporary problems of the science and the education, N3. Available at: https://science-education.ru/ru/article/view?id=29772 
Strategy for development of higher education in Republic of Bulgaria 2021-2030. (2021). Available at: https://www.mon.bg/bg/143.

\section{Литература}

Токмакова С.И., Бондаренко О.В. и Луницына Ю.В. (2020). Опыт дистанционного обучения студентов стоматологического факультета в условиях пандемии COVID-19, Современные проблемы науки и образования, 3. Режим доступа: https://science-education.ru/ru/article/view?id=29772

Гетова, А. (2020). Проблеми и предизвикателства пред дистанционното обучение по време на извънредно положение (доклад). Режим доступа: https://phls.uni-sofia.bg/article/3052.

Гетова, А. (2021). Нагласи и очаквания към онлайн обучението през втората година на пандемията (доклад). Режим доступа: https://phls.uni-sofia.bg/article/3052

Angelova, M. (2020). Students' Attitudes to the Online University Course of Management in the Context of COVID-19, International Journal of Technology in Education and Science (IJTES), 4(4), 283-292.

Biernacki, P, and D Waldorf. (1981). Snowball Sampling: Problems and Techniques of Chain Referral Sampling. Sociological Methods and Research, 10, 2, Sage Publications, 141-163

Doolan, Karin et al. (2020). Student Life during the COVID-19 Pandemic Lockdown: Europe Wide Insights, Draft Report. Режим доступа:

http://www.ehea.info/Upload/BFUG_DE_UK_73_11_6_students_Covid_19_survey_results.pdf

Firang, David. (2020). COVID-19 pandemic on international students in Canada. International Social Work, Sage Publications, 63(6), 820-824.

Georgieva-Tsaneva, G., and Serbezova , I. (2021). Online Training and Serious Games in Clinical Training in Nursing and Midwife Education, International Journal of Advanced Computer Science and Applications(IJACSA), 12.

Stoykova, E. and Getova, A. (2021). The "Fast And Dubious" Research On Higher Education During Covid19 Pandemic: Where Did Sociology Go?, Oral presentation at the 15th ESA Conference, Barcelona, Spain. Available at: https://www.europeansociology.org/esa-conference-2021-in-barcelona

Halachev, P. (2009). Educational Challenges for e-Learning in Higher Education in Bulgaria. International Journal of Learning, 16, 6, 737-745.

Mulrooney, Hilda Mary, and Helly Alison Faith (2020). COVID-19 and the move to online teaching: impact on perceptions of belonging in staff and students in a UK widening participation university. Journal of Applied Learning \& Teaching, 3, 2, 1-14.

Kraska-Miller, M. (2014). Nonparametric Statistics for Social and Behavioral Sciences, Boca Raton, CRC

Press.

Kuleva, M. (2020). The impact of COVID-19 Pandemic on the evaluation of the effectiveness of online distance learning. Pedagogy, 92, 7S, 74-83

Стратегия за развитие на висшето образование в България: 2021-2030. (2021). Режим доступа: https://www.mon.bg/bg/143.

Дата получения рукописи: 10.11.2021

Дата окончания рецензирования: 30.11 .2021 Дата принятия к публикации: 26.11.2021

\section{Информация об авторе}

Гетова Антоанета Георгиева - доктор социологических наук, Софийский университет Св. Климента, г. София, Болгария; e-mail: tony22a@gbg.bg

Автор заявляет об отсутствии конфликта интересов

Information about the author

Getova Antoaneta Georgieva - Doctor of Sociological Sciences, Sofia University "St. Kliment Ohridski", Sofia, Bulgaria; e-mail: tony22a@gbg.bg 